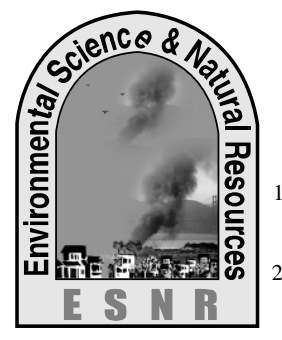

\title{
Comparative Harvesting and Threshing Cost of Paddy by Combine Harvester and Self-propelled Reaper and Thresher
}

\author{
S. M. S. Alam ${ }^{1}$, M. Rashedujjaman ${ }^{2}$, M. M. Hossain ${ }^{2 *}$ and K. M. D. Hossain ${ }^{1}$
}

${ }^{1}$ Department of Agro Product processing Technology, Jessore University of Science and Technology, Jessore-7408, Bangladesh,

${ }^{2}$ Department of Farm Power and Machinery, Bangladesh Agricultural University, Mymensingh-2202, Bangladesh

*Corresponding author: mosharraf53@yahoo.com

\begin{abstract}
Harvesting is one of the major costs for rice production. Although the use of machine for harvesting rice in Bangladesh is increasing day by day and the machines are either combine harvester or reaper and thresher. Farmers of Bangladesh don't have specific information to the choice of these machines. So to determine the cost of use of each machine, a study was conducted in Doyalsara, Bogra and Mymensingh region. Data were collected for rice in the Aman and Boro season of 2015 to determine the cost of harvesting by combine harvester and reaping and threshing by reaper and thresher. It was found for combine harvester operational cost and for carrying rice bag and straw to the plot side was Tk.10,447/ha. On the other hand, for reaper and thresher, the reaping, binding, carrying the rice to the plot side, threshing and cleaning required Tk.6,940/ha. The percentage of cost of combine harvester in relation to reaper and thresher for the same work is higher by $50.53 \%$. In the socio-economic condition of Bangladeshi farmers, harvesting and threshing operations done by using self-propelled reaper and close drum thresher is cost effective and reasonable.
\end{abstract}

Key words: Combine harvester, Reaper and Thresher

\section{Introduction}

Rice is the staple food in Bangladesh and grown during the whole year in different seasons such as Rabi, Kharif named as Aus, Aman and Boro. It has a great contribution on Agricultural economy of Bangladesh. Land and weather is suitable for growing of rice in Bangladesh. Except southeastern hilly region rice is grown throughout the country (Shelley et al., 2016).

Along with other agricultural operations harvesting plays an important role on production cost of rice. Harvesting is the process of collecting the mature rice crop from the field. Harvesting of paddy includes cutting, stacking and handling, threshing and cleaning. Labour scarcity, harvesting loss, timely harvesting and harvesting cost are crucial in rice and wheat harvesting in Bangladesh (Hossain et al., 2015). The goal of good harvesting methods is to minimize grain loss, and to minimize production cost, grain damage and quality deterioration. Harvesting can be done manually using sickles and knives, or mechanically with the use of reaper or combine harvesters. Regardless of the method, a number of guidelines should be followed that will ensure that harvest losses are kept to a minimum and grain quality is preserved during harvesting operations. Guidelines for proper harvesting includes harvest at the right time and moisture content, avoid delays in threshing after harvesting, use the proper machine and settings of machine when using a threshing machine, clean the grain properly after threshing and avoid delay in drying after threshing. Mechanization is needed to raise productivity in rain fed upland and rain fed lowland and to increase cropping intensity in irrigated farms. Metwalli et al. (2006) reported that walking type vertical conveyer reaper, power tiller and tractor front mounted reaper save $50-60 \%$ labor and harvesting cost by $60-70 \%$ as compared to manual harvesting. Use of pedal operated thresher, motorized hold on thresher reduce time, labor, cost of threshing to a great extent. Combine harvesting save $40-50 \%$ cost as compared to manual harvesting and threshing by power thresher (Morad et al., 1995).
During the harvesting season the weather condition may change uncertainly such as heavy rain, storm, sudden flood etc. In addition to this labor demand become very high at the time of peak harvesting season (Chand et al., 2002; Leonce et al., 2015). For harvesting and threshing of paddy, the demand of machine is drastically increased in Bangladesh day by day and the machines are either combine harvester or reaper \& thresher. Sattar et al. 2015 found that the total grain losses during harvesting and threshing processes with manual plus thresher, reaper plus thresher and combine harvester were $222.63 \mathrm{~kg} \mathrm{ha}^{-1}, 199.41 \mathrm{~kg} \mathrm{ha}^{-1}$ and $149.87 \mathrm{~kg} \mathrm{ha}^{-1}$ which were $4.28 \%, 3.85 \%$ and $2.92 \%$ of the total yield, respectively. However, farmers do not have specific information to the choice of these machines that will be reasonable for them for the purpose of harvesting and threshing. Selection of proper harvesting method and equipment depends upon number of factors such as farm size, farmers' constraints, crop constraint, availability of labor, and time limitation (Ojha et al., 2008). Therefore farmers need a proper guideline to choose the cost effective machine, so that the production cost of rice can be minimized and profit can be increased. As the price of rice is low so, minimization of cultivation cost is very much important for farmers. Hence, this study aimed to determine the total cost of use of self-propelled reaper, close drum thresher and combine harvester.

\section{Materials and Methods}

The experimental data were collected from some rice based cropping area of Bogra and Mymensingh districts in Bangladesh. The field survey was conducted by interviewing identified sample respondents with predetermined interview schedules to cover all selected locations. All information about reaper, thresher and combine harvester was collected from the field during operation.

\section{Reaper}

The VIKYNO reaper, close drum thresher and DAEDONG combine harvester were used for the 
experiment. The specifications of VIKYNO reaper

imported by ACI motor is shown in Table 1.

Table 1. The specification of the VIKYNO reaper

\begin{tabular}{ll}
\hline Model & NP120R \\
\hline Brand & HONDA - Made in Thailand \\
Engine type & 4 cycle, air-cooled gasoline \\
Maximum output & $6.5 \mathrm{hp} / 3600 \mathrm{rpm}$ \\
Wheel & Tubeless tire \\
Fuel & Gasoline \\
Delivery & Revolving chain with lug plates \\
Operation and control & Dog clutch \\
Width of cut & $1.2 \mathrm{~m}$ \\
Cutting height & $0.1 \mathrm{~m}-0.4 \mathrm{~m}$ \\
Cutting device & Reciprocating knife bar \\
Dimensions $(\mathrm{L} \times \mathrm{W} \times \mathrm{H})$ & $2.0 \mathrm{~m} \times 1.35 \mathrm{~m} \times 1.1 \mathrm{~m}$ \\
Option & Cage wheel $480 \mathrm{~mm} \times 240 \mathrm{~mm}$ \\
Capacity & Rice: $0.263 \mathrm{ha} / \mathrm{hr}$ \\
\hline
\end{tabular}

\section{Thresher}

Close drum thresher is now manufactured in many agricultural machinery workshops in Bangladesh. The specifications of the close drum thresher used for the experiment is shown in Table 2.

Table 2. The specification of the close drum thresher

\begin{tabular}{ll}
\hline Name & Close Drum Thresher (Alim Industries) \\
\hline Size & $170 \mathrm{~cm} \times 160 \mathrm{~cm} \times 168 \mathrm{~cm}$, cylinder dia: $60 \mathrm{~cm}$, cylinder length: $80 \mathrm{~cm}$ \\
& spike size: dia: $12 \mathrm{~cm}$, length: $30 \mathrm{~cm}$ \\
Engine type & 4 cycle, Diesel Engine \\
Power Requirement & $9 \mathrm{hp}$ \\
Weight & $160 \mathrm{~kg}$ \\
Fuel & Diesel \\
Threshing Capacity & Rice: $930 \mathrm{~kg} / \mathrm{hr}$ \\
\hline
\end{tabular}

\section{Combine Harvester}

The specifications of the DAEDONG combine harvester imported by ACI motors is given in Table 3 .

Table 3. The specification of the combine harvester

\begin{tabular}{ll}
\hline Name & DAEDONG \\
\hline Model & DSC-48 combine harvester \\
$\mathrm{L} \times \mathrm{W} \times \mathrm{H}$ & $4340 \times 1780 \times 2270 \mathrm{~mm}$ \\
Engine & 4 cylinder, water cooled \\
Engine Output & $50 \mathrm{hp}$ \\
Weight & $2180 \mathrm{~kg}$ \\
Fuel & Diesel \\
Capacity & Rice: $0.263 \mathrm{ha} / \mathrm{hr}$ \\
\hline
\end{tabular}

\section{Methods of cost calculation}

\section{Operation Cost}

The selection of machines for agricultural activities is usually depends on least cost operation criteria. Machinery cost consists of fixed cost and variable cost. Fixed cost includes depreciation, interest, shelter and variable cost includes labor, repair and maintenance, fuel, oil etc. Three assumptions were taken during the analysis of cost i.e. the cost was calculated using database of a single year, inflation rate were ignored in the calculation, interest rate was assumed to be $12 \%$.

\section{Fixed cost}

Fixed cost is defined as one, which not change when level of output alters (i.e. it applies to a resource that is fixed in quantity). Fixed cost comprises those costs, which have to bear regardless of the machine is used, namely, depreciation, housing, interest on investment and tax (if any). Fixed costs are fixed in total, but decline per ha, as the annual use of machine is increased (Barnard et al., 1979).

\section{Depreciation}

In agricultural engineering management an update equation is developed for calculating the depreciation considering time equivalent of money as given below (DeGermo et al., 1979):

Depreciation, $\mathrm{D}=\frac{P * \bar{i}(1+i)^{\mathrm{L}}}{(1+i)^{\mathrm{L}}-1}+\frac{S * \bar{i}}{(1+i)^{\mathrm{L}}-1}$

Where, $i$ is the interest rate in decimal, $P$ purchase price, $L$ is length of life (year), $S$ is the salvage value. The interest on investment in a farm machine was included in fixed cost estimation. Even if the investment money was not actually borrowed, a charge was made since that money cannot be used for some other interest paying enterprises. The following equation was used for the calculation of interest on investment. 


\section{Interest on investment}

Interest on investment, $I=\frac{p+S}{2} \times i$

\section{Housing}

Housing cost was calculated, SLT $=0.75 \%$ of $P$

Fixed cost (F.C) Tk./ha= Depreciation (D) + Interest (I) + Housing charge (SLT) [Cost of insurance and taxes was not considered]

\section{Variable cost}

The variable cost is one which changes when the level of output alters. Variable costs vary in total in proportion to annual use, but are approximately constant per ha (Barnard et al., 1979). Variable costs depend on hourly labor cost, repair and maintenance cost, fuel and oil cost and the required working hours for each field operation.

Variable cost (V.C) Tk./ha $=$ fuel cost + oil cost + labor cost + repair and maintenance $\operatorname{cost}(\mathrm{R} \& \mathrm{M})$

\section{Working procedure}

In Doyalsara, Bogra there was going an Aman rice harvesting project conducted by ACI Motor and it was selected as working area. Besides this experiment was conducted in the Bangladesh Agricultural University agronomy farm.

\section{Data collection for Combine harvester and Reaper}

The following necessary data for calculating total cost of use of combine harvester and reaper were collected: purchase price, economic life, price of each type of fuel, fuel consumption. Before starting the machine the fuel tank was filled with diesel or petrol. After the operation the fuel tank was refilled with fuel and the necessary amount of fuel to refill the tank was recorded. Cutting width was measured by tape. For a particular distance travelled by the machine, the time was recorded.

The fuel cost and forward speed were calculated by the following equation:

$>\quad$ Fuel Cost $=$ fuel consumption*fuel cost/lit
Forward speed, $\mathrm{S}=\frac{3.6 \mathrm{D}}{\mathrm{t}}$

Where, $\mathrm{S}=$ forward speed, $\mathrm{km} / \mathrm{hr}, \mathrm{D}=$ distance travelled, $\mathrm{m} ; \mathrm{t}=$ time required, $\mathrm{sec}$

$>\quad$ Labor requirement and cost: The total number of operator, helper, and laborer needed during the operation for operating the machine, collecting the rice grain from combine harvester, carrying the grain to the road side and bagging with their wages were recorded.

$>\quad$ Daily use and yearly use

$>$ Field capacity: The field capacity of the machine was obtained by the area covered by the machine divided by time required to cover the area. The following equation was used to calculate the field capacity:

Field capacity $=\frac{A}{t}$

Where, $\mathrm{A}=$ area covered by the machine, ha; $\mathrm{t}=$ time required to cover the area, $\mathrm{hr}$

Data collection for thresher: The following necessary data for calculating total cost of use of thresher were collected: purchase price, economic life, price of each type of fuel, fuel consumption, labor requirement and cost, daily use and yearly use.

Capacity: The capacity of thresher was calculated by the following equation:

Capacity $=\frac{\text { Threshed grain weight }(\mathrm{kg})}{\text { time }(\mathrm{hr})}$

Comparison of the result: Finally result was compared between the cost of use for harvesting and threshing of paddy by using combine harvester with self-propelled reaper $\&$ close drum thresher in percentage.

\section{Results and Discussion}

Table 4 shows the comparison of different particulars of combine harvester, reaper and thresher. Purchase price of new combine harvester was much higher compared to reaper and thresher. It was around 7.6 times higher than the total purchase price of new reaper and thresher.

Table 4. Performance results of harvesting and threshing of paddy by different methods

\begin{tabular}{llll}
\hline Particular & Combine Harvester & Reaper & Thresher \\
\hline Purchase Price, P (Tk.) & $21,00,000$ & 1,90000 & 85,000 \\
Life, L (Year) & 7 & 5 & 5 \\
Salvage Value, S =10\% of P & $2,10,000 \mathrm{Tk}$. & $19,000 \mathrm{Tk}$. & $85,00 \mathrm{Tk}$. \\
Interest, I (\%) & 12 & 12 & 12 \\
Housing Charge, SLT & $0.75 \%$ of P & $0.75 \%$ of P & $0.75 \%$ of P \\
Repair \& Maintenance cost/hr & $0.025 \%$ of P & $0.025 \%$ of P & $0.025 \%$ of P \\
Fuel consumption & 7 liter $/ \mathrm{hr}$ & $1 \mathrm{liter} / \mathrm{hr}$ & $1.25 \mathrm{liter} / \mathrm{hr}$ \\
Forward Speed & $4 \mathrm{~km} / \mathrm{hr}$ & $3 \mathrm{~km} / \mathrm{hr}$ & $\mathrm{N} / \mathrm{A}$ \\
Cutting Width & $1.45 \mathrm{~m}$ & $1.2 \mathrm{~m}$ & $68 \mathrm{Tk} . / \mathrm{lit}$ \\
Fuel Cost & $68 \mathrm{Tk} / \mathrm{lit}$ & $96 \mathrm{Tk} / \mathrm{lit}$ & $80 \mathrm{days} / \mathrm{yr}$ \\
Yearly use & $80 \mathrm{days} / \mathrm{yr}$ & $80 \mathrm{days} / \mathrm{yr}$ & $8 \mathrm{hr} / \mathrm{day}$ \\
Daily use & $8 \mathrm{hr} / \mathrm{day}$ & $8 \mathrm{hr} / \mathrm{day}$ & 1250 \\
Capacity & $0.263 \mathrm{ha} / \mathrm{hr}$ & $0.263 \mathrm{ha} / \mathrm{hr}$ & $0.25 \mathrm{ha} / \mathrm{hr}$ \\
& & & $3 \mathrm{nos}$. \\
Labor required, per ha & 1operator+1helper+5labor for & 1 loperator+1helper+15la \\
& carrying rice to the plot side+ bour for binding and & 5labour for collection of straw carrying the rice to the \\
\hline
\end{tabular}


Fuel cost for combine harvester, reaper and thresher was $476 \mathrm{Tk} . / \mathrm{hr}, 90 \mathrm{Tk} . / \mathrm{hr}$ and $85 \mathrm{Tk} . / \mathrm{hr}$ respectively. Cutting width and forward speed of combined harvester was higher than reaper, which resulted the more capacity of combine harvester compared to reaper. There were maximum number of labor were required for operation of combine harvester i.e., total twelve number (one operator, one helper, five labor for carrying rice to the plot side, five labor for collection of straw and carrying to the plot side), where two number (one operator and one helper with machine) of labor were required for reaper for reaping operation, and after reaping fifteen labor were required for binding and carrying the rice to the plot side for threshing.

Table 5. Cost comparison between combine harvester with reaper and thresher

\begin{tabular}{|c|c|c|c|}
\hline \multirow[t]{2}{*}{ Operations } & \multicolumn{3}{|c|}{ Machine Cost $\left(\mathrm{Tk} \mathrm{ha}^{-1}\right)$} \\
\hline & Combine Harvester & Reaper & Thresher and cleaning \\
\hline Harvesting & $8,947 /-$ & $1,319 /-$ & \\
\hline $\begin{array}{l}\text { Collection of straw and carrying to the plot } \\
\text { side }\end{array}$ & $1,500 /-$ & & \\
\hline Reaping & & & \\
\hline $\begin{array}{l}\text { Binding for threshing and carrying the rice to } \\
\text { the plot side }\end{array}$ & & $4,500 /-$ & \\
\hline Threshing and cleaning & & & $1,121 /-$ \\
\hline Total operating cost & $10,447 /-$ & $5,819 /-$ & $1,121 /-$ \\
\hline Cost comparison & $10,447 /-$ & $6,940 /-($ & er \& Thresher) \\
\hline
\end{tabular}

The Table 5 represents the harvesting cost comparison of combine harvester with reaper and thresher for paddy.

The results were found from cost calculation for combine harvester, self-propelled reaper and closed drum thresher included fixed cost and variable cost. It was found that for combine harvester operational cost was Tk.8,947/ha, and Tk.1500/ha was required for carrying rice bag and straw to the plot side. So the total cost of use of combine harvester was Tk.10,447/ha. On the other hand, for reaper the reaping cost was Tk.1,319/ha, and cost for binding, and carrying the rice to the plot side required Tk.4,500/ha and the total cost for reaper was found Tk.5,819/ha. And threshing cost by a close drum thresher and cleaning including labor was found Tk.1,121/ha. So the total cost of use of reaper and thresher along with binding and carrying was taken Tk.6,940/ha. The percentage of cost of combine harvester in relation to reaper and thresher for the same work is higher by $50.53 \%$. In the socio-economic condition of Bangladeshi farmers, harvesting and threshing operations done by using self-propelled reaper and close drum thresher is cost effective and reasonable.

\section{Conclusions}

From the study it was found that the cost of use of combine harvester was higher than the cost of use of reaper and thresher for harvesting and threshing of paddy in Bangladesh condition. The initial cost of combine harvester is very much higher in comparison with the initial cost of reaper and thresher. Most of the Bangladeshi farmers has small amount of land. In this case, rather than combine harvester the reaper and thresher are easily portable and maneuverable. Hence in terms of initial investment and cost of use for harvesting and threshing of paddy reaper and thresher are more acceptable rather than combine harvester. So it can be concluded that with present socio-economic condition of rural farmers of Bangladesh for harvesting of paddy the use of reaper and thresher are more suitable and reasonable. Harvesting of paddy by combine harvester is quick and three operations ie., harvesting, threshing and cleaning are done together but not economically viable for individual farmer. For individual farmers harvesting by reaper and threshing by closed drum thresher are economic. Combine harvester may be economically viable for commercial use.

\section{References}

Shelley, I. J.; Nosaka, T.; Nakata, M. K.; Haque, M.; Haqueand, M. S. and Inukai, Y. 2016. Rice cultivation in Bangladesh: present scenario, problems and prospects. J. Intl. Agric. Dev., 14: 20.

Hossain, M. A.; Hoque, M. A.; Wohab, M. A.; Miah, M. A. M. and Hassan, M. S. 2015. Technical and economic performance of combined harvester in farmers' field, Bangladesh J. Agril. Res., 40(2): 291.

Metwalli, M. M.; Helmy, M. A.; Gomaa, S. M. and Khateeb, H. A. 2006. Evaluation of different mechanical methods of cutting and choppingcotton stalks. Misr Journal of Agricultural Engineering, 12(1): 205.

Morad, M. M. 1995. Optimizing the rotary mower kinematic parameter for minimum cost. Misr J. Agric. Eng., 12(2).

Chand, R. and Kumar, P. 2002. Long-term changes in course cereal consumption in India. Indian Journal of Agricultural Economics, 57(3).

Leonce, H. and Saraswat, D. C. 2015. Comparative Study of Performance and Economics of Self Propelled Combine Harvester with Other Harvesting and Threshing Methods on Paddy Rice. Journal of Emerging Trends in Engineering and Applied Sciences (JETEAS), 6(6): 377.

Sattar, M.; Din, M.; Ali1, M.; Ali, L.; Waqar, M. Q.; Ali, M. A. and Khalid, L. 2015. Grain losses of wheat as affected by different harvesting and threshing techniques. International Journal of Research in Agriculture and Forestry, 2(6): 20.

Ojha, T. P. and Michael, A. M. 2008. Principles of Agricultural Engineering. Jain Brothers, New Delhi.

Barnard, C. S. and Nix, J. S. 1979. Farm planning and Control. Cambridge University Press, Cambridge, London.

DeGermo, E.P.; Canada, J. R. and Sullivan, W, G. 1979. Engineering Economy. Macmillan Publishing Co. In., New York, USA. 